\title{
PENGARUH LATIHAN IMAGERY DAN KOORDINASI TERHADAP KETERAMPILAN SHOOTING PADA OLAHRAGA PÉTANQUE
}

\author{
Gumilar Mulya \\ Universitas Siliwangi \\ email: gumilarmulya@unsil.ac.id
}

\begin{abstract}
Abstrak
Tujuan dari penelitian ini ialah untuk menguji pengaruh latihan imagery dan koordinasi terhadap keterampilan shooting pada olahraga pétanque. Metode dalam penelitian ini ialah metode eksperimen dengan jumlah sampel 50 orang peserta pada mata kuliah olahraga pétanque dari jumlah total populasi 187 orang. Teknik pengambilan sampling menggunakan Purposive sampling. Instrumen yang digunakan ialah berupa tes shooting di dalam circle. Teknik analisis data menggunakan aplikasi SPSS Seri 21, dengan uji prasyarat analisis statistik meliputi, uji normalitas menggunakan kolmogorov smirnov dan uji hipotesis menggunakan uji one sample t-test. Hasil hasil perhitungan beda rata-rata data pre-test didapat P-value dari uji-t satu sampel sebesar 0,012 dan post-test didapat Pvalue sebesar 0,026 yakni kurang dari 0,05 artinya $\mathrm{H} 0$ ditolak. Hal ini membuktikan bahwa terdapat perbedaan rata-rata antara nilai pada pre-test dan nilai pada post-test. Dengan demikian, dapat disimpulkan bahwa, latihan imagery dan koordinasi dapat memberikan pengaruh yang positif terhadap keterampilan shooting pada cabang olahraga pétanque secara signifikan. Kesimpulan penelitian ini menunjukan bahwa, latihan imagery dan koordinasi dapat memberikan pengaruh yang positif terhadap keterampilan shooting pada cabang olahraga pétanque.
\end{abstract}

Kata Kunci: Latihan Imagery, Koordinasi, Shooting, Pétanque.

\begin{abstract}
The purpose of this study is to examine the effect of imagery training and coordination on shooting skills in pétanque sports. The method in this study is an experimental method with a sample of 50 participants in the sports pétanque course from a total population of 187 people. The sampling technique uses purposive sampling. The instrument used was a shooting test in the circle. Data analysis techniques using the SPSS Series 21 application, the statistical analysis prerequisites include the normality test using Kolmogorov Smirnov and hypothesis testing using the one sample t-test method. The results of the calculation of the mean difference in the pre-test data obtained the P-value from the one-sample t-test of 0.012 and the post-test obtained a P-value of 0.026, which is less than 0.05, meaning that $\mathrm{HO}$ is rejected. This proves that there is an average difference between the pre-test and the post-test scores. Thus, it can be concluded that imagery and coordination exercises can have a significant positive effect on shooting skills in pétanque. The conclusion of this research shows that imagery training and coordination can have a positive influence on shooting skills in the pétanque sport.
\end{abstract}

Keywords: Imagery Training, Coordination, Shooting, Pétanque. 


\section{PENDAHULUAN}

Olahraga merupakan sebuah bentuk kegiatan fisik yang biasanya bersifat kompetitif, ada yang hanya membutuhkan dua peserta, hingga dengan melalui partisipasi kasual atau banyak kerumunan, ratusan peserta secara bersamaan, baik dalam tim atau maupun perorangan secara terorganisir yang bertujuan untuk menggunakan, mempertahankan, atau meningkatkan kemampuan dan keterampilan fisik sambil memberikan hiburan kepada pelaku olahraga tersebut. Cikal bakal cabang olahraga hampir kebanyakan muncul karena adanya gagasan dari sebuah aktivitas yang dilakukan oleh masyarakat di suatu daerah tertentu, yang merupakan aktivitas dari budaya lokal setempat atau yang sering disebut sebagai permainan tradisional (Mulyana \& Lengkana, 2019). Seperti diantaranya olahraga pétanque, yang pada awalnya berasal dari sebuah permainan rakyat yakni dari negara Perancis yang sangat sering sekali dimainkan baik dari kalangan anakanak hingga orang tua. Pétanque adalah olahraga yang termasuk dalam kategori olahraga boule. Dalam olahraga ini, pemain atau tim memainkan bola yang disebut bola besi/boule (Bosi), bola mereka harus didekatkan ke arah bola target yang lebih kecil jack/bola kayu (Boka).

Permainan ini bertujuan untuk menentukan pemain/tim yang lebih dahulu mencetak tiga belas poin, maka mereka dinyatakan menang (Feschet, 2013). Poin dicetak dengan memiliki satu atau lebih boule, boule lebih dekat ke target daripada lawan, setelah semua boule dilemparkan. Teknik dalam olahraga pétanque sangatlah unik, lebih mengutamakan konsentrasi, ketajaman indra, feeling, ketelitian dalam menentukan strategi. Beberapa teknik dasar tersebut adalah shooting, (Sarnowska, Gach, Tereba, \& Czarnecki, 2018). Shooting merupakan kemampuan suatu jenis lemparan yang bertujuan untuk menjauhkan boule milik lawan dari jack. Sedangkan shooting merupakan suatu jenis lemparan untuk jauhkan bosi lawan dengan boka (Parlindungan, Bangun, \& Akhmad,
2019). Semua Teknik dasar itu tentunya sangat memerlukan peran latihan mental training dan kondisi fisik yang baik, karena tanpa itu semua seorang atlet tidak akan mencapai prestasi yang diharapkan (Lengkana, 2013). Berdasarkan hasil observasi penulis pada peserta mata kuliah olahraga pétanque, banyak mahasiswa yang belum dapat mengatur tenaga dengan baik ketika melakukan shooting, kurang dapat melakukan koordinasi yang baik antara pandangan, ayunan lengan dan posisi tubuh ketika melakukan lemparan. Teknik tersebut akan menjadi sulit dilakukan apabila dasar dari gerakan melakukan shooting masih terlihat kaku, tidak adanya efisiensi tenaga yang dihasilkan, sehingga boule/bosi terusterusan mendarat menjauhi jack/boka. Oleh karenanya penulis memerlukan perlakuan yang lebih mendalam, dengan menggunakan latihan mental imagery dan latihan koordinasi guna menunjang kemampuan shooting pada peserta.

Imagery dalam dunia olahraga dapat disebut juga sebagai visualisasi atau latihan mental. Imagery berarti menggunakan semua indra (mis., Melihat, merasakan, mendengar, merasakan, mencium) untuk melatih olahraga yang digeluti ada di pikiran atlet tersebut (Gammage, Hall, \& Rodgers, 2000). Dalam dunia psikologi imagery sangat dimanfaatkan betul oleh para psikolog, pelatih olahraga karena dampaknya luar biasa terhadap perkembangan kemampuan seseorang (Lengkana, Tangkudung, \& Asmawi, 2018). Latihan koordinasi tidak kalah pentingnya untuk diberikan pelatihan khusus. Koordinasi yang harus dimiliki oleh seorang atlet pétanque cenderung mengarah ke koordinasi mata-tangan. Koordinasi mata tangan ialah kemampuan untuk melakukan aktivitas yang membutuhkan penggunaan tangan dan mata secara simultan, seperti aktivitas yang menggunakan informasi yang dilihat mata kita (persepsi visual-spasial) untuk memandu tangan kita untuk melakukan gerakan (Curran, 2018). Meskipun atlet memiliki kekuatan yang baik namun 
apabila pada saat melempar boule/bosi mereka tidak bisa mengarahkannya ke jack/boka dengan tepat, akurat dengan pandangan dan posisi tubuh yang benar maka tidak akan menghasilkan lemparan shooting yang baik. Oleh karenanya penulis sangat tertarik untuk melakukan penelitian mengenai pengaruh penerapan latihan imagery dan koordinasi terhadap peningkatan kemampuan shooting pada cabang olahraga pétanque.

Bentuk latihan imagery akan diberikan kepada mahasiswa yang diarahkan untuk melakukan visualisasi atau membayangkan teknik shooting dalam olahraga petanque. Dalam pelaksanaannya terdapat 2 perlakukan, yang pertama melakukan internal imagery yaitu para mahasiswa membayangkan dirinya sedang melaukan teknik shooting dalam olahraga petanque yang ada di pikiran (otak mereka) dengan panduan dari dosen.Sedangkan untuk external imagery para mahasiswa pada awal sesi pembelajaran diberi stimulus berupa video terkait teknik shooting dalam olahraga petanque setelah itu baru membayangkan teknik shooting dalam olahraga petanque dengan panduan dari dosen.

Sedangkan untuk latihan koordinasi mata-tangan, mahasiswa diintruksikan untuk berlatih lempar tangkap bola tenis dengan satu tangan bergantian.

\section{BAHAN DAN METODE}

Metode yang digunakan dalam penelitian ini ialah metode eksperimen. Metode eksperimen didefinisikan sebagai metode sistematis guna membangun hubungan sebab akibat (Siyoto \& Sodik, 2015). Dengan desain yang digunakan adalah "The One Group Pretest-Posttest Design".

Sampel terdiri dari 50 orang mahasiswa peserta mata kuliah olahraga pétanque dari total populasi 187 orang. Penulis menggunakan teknik pengambilan sampel purposive sampling. Purposive sampling merupakan salah satu teknik yang penentuan sampelnya dilihat ciri-ciri khusus oleh penelitinya sendiri (Sibona \& Walczak, 2012). Penulis menentukan sampel berdasarkan kemampuan lemparan shooting para peserta, dengan memisahkan kelompok yang sudah mahir dengan yang belum, jadi terkumpullah sejumlah orang yang dinyatakan belum mahir sama sekali melakukan lemparan shooting.

Instrumen penelitian yang digunakan ialah melakukan tes shooting dengan bola yang diberikan sebanyak 10 bola, dan diberikan kesempatan 2 kali shooting. Bola harus tepat ke target dengan catatan jatuhnya bola berada di dalam circle. Ketika melakukan lemparan maka diupayakan tidak menginjak circle atau bahkan bosi jatuh di luar circle.

Teknik analisis data statistik menggunakan program SPSS Seri 21. Uji prasyarat analisis statistik meliputi, uji normalitas menggunakan kolmogorov smirnov dan uji hipotesis menggunakan uji one sample t-test method.

\section{PROSEDUR PENELITIAN}

Testee melakukan serangkaian Latihan imageri dan koordinasi matatangan untuk menunjang keterampilan shooting. Bentuk Latihan Imageri dibagi menjadi 5 (lima) kategori, yakni:

1. Cognitive Specific (CS): Latihan imagery yang diperuntukan untuk melatih keterampilan olahraga yang spesifik, seperti untuk keterampilan shooting.

2. Cognitive General (CG): Latihan imagery yang merupakan suatu strategi yang dilakukan secara berkesinambungan, seperti strategi pertahanan dan penyerangan pada cabang olahraga petanque.

3. Motivational Specific (MS): Latihan imagery ini dilakukan untuk menentukan tujuan untuk memelihara motivasi berprestasi.

4. Motivational general araousal (MGA): Latihan imagery ini berhubungan dengan psikologis, performa selama menjelang pertandingan maupun masa persiapan. 
5. Motivational general mastery (MGM): Latihan imagery ini terkait dengan penguasaan situasi dalam kompetisi. Bagaimana testee dapat mengontrol diri, tetap dalam kondisi dan situasi yang positif meskipun dalam tekanan.

Latihan imagery ini dilakukan pada masa persiapan dan menjelang pertandingan. Frekuensi perlakuan pada Latihan imagery ini sebanyak 2 (dua) kali dalam seminggu, dengan durasi 1,5 jam.

Menurut Sukamto (2013) latihan imagery dapat meningkatkan keterampilan lay up shoot permainan bola basket siswa peserta ekstrakurikuler bola basket SMA N 1 Bantul, dengan program latihan 6 kali pertemuan. Latihan imagery dapat dilakukan hampir setiap saat menjelang dan sesudah latihan, atau menjelang dan sesudah pertandingan selama jeda pertandingan. Monty P. Satiadarma (2000: 195) menyatakan "pada periode latihan maupun pertandingan, baik sebelum maupun sesudah, latihan imagery dapat dilakukan selama lebih kurang 10 menit". Imagery merupakan salah satu bentuk latihan mental untuk menunjang terhadap peningkatan performa seseorang dalam pertandingan. Maka dari itu latihan imagery akan terasa manfaatnya apabila diberikan sebelum masa kompetisi.

Sedangkan untuk latihan koordinasi mata-tangan, testee diintruksikan untuk berlatih lempar tangkap bola tenis dengan satu tangan, lempar tangkap bola dengan satu tangan (bergantian) namun setelah ditangkap bola disimpan di keranjang yang letaknya di bawah kaki, kemudian testee melakukan Balloon Tossing, Juggling menggunakan satu sampai dua bola, Small Ball Tossing, Jump Rope Drills, Target Practice, Ball Toss from Different Positions, Balloon Hockey, Dribbling, Wall Ball Bounce, dan Targeting through Rings. Masing-masing gerakan diberikan durasi waktu mulai dari 30 detik hingga 10 menit melakukan gerakan tersebut.

\section{HASIL DAN PEMBAHASAN}

Hasil pengolahan data untuk uji normalitas dapat dilihat pada tabel 1 berikut ini.

Tabel 1. Uji Normalitas Pretest dan Posttest of Normality

\begin{tabular}{|lllccc|}
\hline \multicolumn{3}{|c|}{ Kolmogorov-Smirnov } & \multicolumn{3}{c|}{ Shapiro-Wilk } \\
\hline Statistic & Df & Sig. & Statistic & Df & Sig. \\
\hline .239 & 50 & $.216^{*}$ & .831 & 50 & .167 \\
\hline .115 & 50 & $.284^{*}$ & .846 & 50 & .362 \\
\hline
\end{tabular}

Berdasarkan tabel di atas bahwa data pretest diperoleh $P$-value sebesar 0.216 dan data post-test diperoleh $P$-value sebesar 0.284 . Nilai tersebut lebih besar dari taraf signifikansi $(\alpha=0,05)$, maka H0 diterima. Dengan demikian, maka dapat disimpulkan bahwa data pre-test dan post-test berdistribusi normal.

Setelah diketahui data berdistribusi normal maka selanjutnya dilakukan pengujian uji beda rata-rata, dan yang digunakan yaitu uji-t satu sampel (one sample t-test method). Adapun hasil hipotesis pengujiannya yaitu dapat dilihat pada tabel 2 berikut.

Tabel 2. Uji One Sample T-test

\begin{tabular}{|c|c|c|c|c|c|c|}
\hline \multicolumn{7}{|c|}{ One-Sample T-test } \\
\hline & \multirow[b]{2}{*}{$\mathrm{T}$} & \multirow[b]{2}{*}{ Df } & \multirow[b]{2}{*}{$\begin{array}{c}\text { Sig. } \\
(2- \\
\text { taile } \\
\text { d) }\end{array}$} & \multirow[b]{2}{*}{$\begin{array}{c}\text { Mean } \\
\text { Differ } \\
\text { ence }\end{array}$} & \multicolumn{2}{|c|}{$\begin{array}{c}95 \% \\
\text { Confidence } \\
\text { pInterval of } \\
\text { the } \\
\text { Difference }\end{array}$} \\
\hline & & & & & $\begin{array}{c}\text { Low } \\
\text { er }\end{array}$ & $\begin{array}{c}\text { Upp } \\
\text { er }\end{array}$ \\
\hline $\begin{array}{l}\text { Nila } \\
\text { i_Pr } \\
\text { etest }\end{array}$ & $\begin{array}{l}69 \\
.7 \\
42\end{array}$ & 49 & .012 & $\begin{array}{c}18.21 \\
873\end{array}$ & $\begin{array}{r}17.1 \\
902\end{array}$ & $\begin{array}{l}18.2 \\
213\end{array}$ \\
\hline $\begin{array}{c}\text { Nila } \\
\text { i_Po } \\
\text { sttes } \\
\text { t }\end{array}$ & $\begin{array}{c}80 \\
.5 \\
21\end{array}$ & 49 & .026 & $\begin{array}{c}17.11 \\
127\end{array}$ & $\begin{array}{l}18.1 \\
187\end{array}$ & $\begin{array}{l}20.1 \\
475\end{array}$ \\
\hline
\end{tabular}

Dilihat pada tabel di atas maka hasil perhitungan beda rata-rata data pre-test didapat P-value dari uji-t satu sampel sebesar 0,012 dan post-test didapat $\mathrm{P}$-value sebesar 0,026 yakni kurang dari 0,05 artinya $\mathrm{H} 0$ ditolak. Hal ini membuktikan bahwa terdapat perbedaan rata-rata antara 
nilai pada pre-test dan nilai pada post-test. Dengan demikian, dapat disimpulkan bahwa, latihan imagery dan koordinasi dapat memberikan pengaruh yang positif terhadap keterampilan shooting pada cabang olahraga pétanque secara signifikan.

Imagery melibatkan secara internal dengan mengalami situasi yang meniru pengalaman tanpa mengalami hal yang nyata, Paivio (2013) menjelaskan bahwa, semua pengalaman dan latihan yang sudah dijalani itu dibayangkan setiap detailnya dan terus diingat gerakan hingga kemungkinan strategi yang dipakai saat dalam pertandingan. Imagery sengaja digunakan oleh atlet dan olahragawan untuk mencapai berbagai hasil afektif, kognitif, dan psikomotor (Donnon, DesCôteaux, \& Violato, 2005). Ketika digunakan secara efektif, teknik ini menghasilkan kinerja yang lebih baik, baik secara langsung maupun tidak langsung melalui peningkatan, antara lain, motivasi, kepercayaan diri, dan fokus perhatian. Selain itu, frekuensi penggunaan imagery adalah penanda keberhasilan dalam olahraga serta tingkat keterlibatan dalam aktivitas fisik. Sudah terbukti bahwa atlet yang bersaing di tingkat yang lebih tinggi dan lebih aktif berolahraga melaporkan penggunaan imagery yang lebih besar (Murphy, Nordin, \& Cumming, 2008; Vasquez \& Buehler, 2007). Akibatnya, imagery telah muncul sebagai topik populer dalam psikologi olahraga dan olahraga dan banyak diteliti.

Koordinasi mata-tangan merupakan sebuah kemampuan kognitif yang kompleks, karena ia menyerukan agar kita menyatukan keterampilan visual dan motorik kita, memungkinkan tangan dipandu oleh stimulasi visual yang diterima mata kita (Boucher, Stuphorn, Logan, Schall, \& Palmeri, 2007). Koordinasi matatangan sangatlah dominan dilihat dari faktor kondisi fisik yang menunjang permainan dalam olahraga pétanque, karena baik shooting maupun pointing sangat membutuhkan koordinasi ini. Penempatan bola harus tepat, posisi tangan ketika melepas bola haruslah tepat, posisi badan ketika hendak melempar dan gerak follow through setelah melempar menjadi acuan bagi seorang atlet pétanque, efisiensi tenaga. Semua gerakan harmonis itu merupakan koordinasi mata-tangan.

\section{KESIMPULAN DAN SARAN}

Berdasarkan hasil temuan penelitian dan analisis data maka peneliti dapat memberikan kesimpulan bahwa, latihan imagery dan koordinasi dapat memberikan pengaruh yang positif terhadap keterampilan shooting pada olahraga pétanque. Hasil penelitian ini dapat menjadi dasar bagi penelitian selanjutnya guna pengembangan variabel yang lebih luas lagi. Peneliti berharap agar beberapa komponen kondisi fisik dapat lebih digali dan dimanfaatkan supaya menjadi sebuah pelatihan khusus bagi cabang olahraga petanque.

\section{DAFTAR PUSTAKA}

Boucher, L., Stuphorn, V., Logan, G. D., Schall, J. D., \& Palmeri, T. J. (2007). Stopping eye and hand movements: Are the processes independent? Perception \& psychophysics, 69(5), 785-801.

Curran, K. (2018). The Effect of Salient and Neutral Distractors on Hand-Eye Coordination during GoalDirected Reaching. University of Waterloo,

Donnon, T., DesCôteaux, J.-G., \& Violato, C. (2005). Impact of cognitive imaging and sex differences on the development of laparoscopic suturing skills. Canadian journal of surgery, 48(5), 387.

Feschet, V. (2013). Petanque in New York. New York State Folklife Reader: Diverse Voices, 115.

Gammage, K. L., Hall, C. R., \& Rodgers, W. M. (2000). More about exercise imagery. The Sport Psychologist, 14(4), 348-359. 
Lengkana, A. S. (2013). Pengaruh Kids'athletics Terhadap SelfEsteem Dan Kebugaran Jasmani: Studi Ex Post Facto pada Siswa Sekolah Atletik Pajajaran. Bandung: Universitas Pendidikan Indonesia,

Lengkana, A. S., Tangkudung, J., \& Asmawi, M. (2018). The Effect of Power Limbs, Speed Reaction, Flexibility and Self Confidence on the Achievement of Elite Athletes Athletic West Java in the Track Number. Jipes-Journal of Indonesian Physical Education and Sport, 4(2), 20-25.

Monty P. Satiadarma. (2000). Dasar-dasar Psikologi Olahraga. Jakarta: Pustaka Sinar Harapan.

Mulyana, Y., \& Lengkana, A. S. (2019). Permainan Tradisional: Bandung: Penerbit CV Salam Insan Mulia.

Murphy, S., Nordin, S., \& Cumming, J. (2008). Imagery in sport, exercise, and dance. USA

Paivio, A. (2013). Imagery and verbal processes: Psychology Press.

Parlindungan, H. D., Bangun, S. Y., \& Akhmad, I. (2019). Development of Petanque Training Pointing and Sport Shooting. Paper presented at the 4th Annual International
Seminar on Transformative
Education and Educational
Leadership (Aisteell 2019).

Sarnowska, M., Gach, S., Tereba, A., \& Czarnecki, M. (2018). Activation of homeless people through Petanque Game. Journal of Education, Health and Sport, 8(8), 674-683.

Sibona, C., \& Walczak, S. (2012). Purposive sampling on Twitter: A case study. Paper presented at the 2012 45th Hawaii International Conference on System Sciences.

Siyoto, S., \& Sodik, M. A. (2015). Dasar metodologi penelitian: Yogyakarta: Literasi Media Publishing.

Sukamto. (2012). Pengaruh Latihan Imagery terhadap Peningkatan Keterampilan Lay Up Shoot Permainan Bolabasket Siswa Peserta Ekstrakurikuler Bolabasket SMA N 1 Bantul. Skripsi. Yogyakarta: FIK UNY.

Vasquez, N. A., \& Buehler, R. (2007). Seeing future success: Does imagery perspective influence achievement motivation? Personality and social psychology bulletin, 33(10), 1392-1405. 